\title{
Incorporating translation into sociolinguistic research: translation policy in an international non-governmental organisation
}

Article

Accepted Version

Tesseur, W. (2017) Incorporating translation into sociolinguistic research: translation policy in an international non-

governmental organisation. Journal of Sociolinguistics, 21 (5). pp. 629-649. ISSN 1360-6441 doi:

https://doi.org/10.1111/josl.12245 Available at https://centaur.reading.ac.uk/70618/

It is advisable to refer to the publisher's version if you intend to cite from the work. See Guidance on citing.

To link to this article DOI: http://dx.doi.org/10.1111/josl.12245

Publisher: Wiley

All outputs in CentAUR are protected by Intellectual Property Rights law, including copyright law. Copyright and IPR is retained by the creators or other copyright holders. Terms and conditions for use of this material are defined in the End User Agreement. 


\section{CentAUR}

Central Archive at the University of Reading

Reading's research outputs online 


\title{
Incorporating translation into sociolinguistic
}

\section{research: Translation policy in an international}

\section{non-governmental organisation}

\begin{abstract}
$^{1}$
This article explores aspects of translation, multilingualism and language policy in the field of transnational civil society. By focusing on translation policies at Amnesty International, an international non-governmental organisation that performs a key role in global governance, this article seeks to contribute to a globalisation-sensitive sociolinguistics. It argues that combining a sociolinguistic approach, more precisely linguistic ethnography, with translation studies leads to an increased understanding of the language practices under study. Furthermore, the article calls for more interdisciplinary research, stating that there is a space for sociolinguistics and translation studies to contribute to research in international relations and development studies by highlighting the role of multilingualism and challenging the traditionally powerful position of English in transnational civil society.
\end{abstract}

Keywords: linguistic ethnography, translation studies, translation policy, non-governmental organisations, Amnesty International, sociolinguistics of globalisation

Short running title: Incorporating translation into sociolinguistics

Word count: 8665 


\begin{abstract}
Dutch
Dit artikel onderzoekt aspecten van vertalen, meertaligheid en taalbeleid in de transnationale civil society. Door te focussen op het vertaalbeleid van Amnesty International, een internationale non-gouvernementele organisatie die een belangrijke rol speelt in mondiaal bestuur, wil dit artikel bijdragen aan sociolinguïstiek onderzoek dat aandacht schenkt aan globalisering. Het artikel betoogt dat de combinatie van een sociolinguïstische benadering, meer bepaald linguïstische etnografie, met vertaalwetenschap leidt tot een beter begrip van taalpraktijken. Tenslotte roept het artikel op tot meer interdisciplinair onderzoek. Het argumenteert dat de sociolinguïstiek en vertaalwetenschap kunnen bijdragen aan onderzoek in Internationale Relaties en Ontwikkelingsstudies door te wijzen op de rol van meertaligheid en door de traditioneel sterke positie van het Engels in de transnationale civil society te problematiseren.
\end{abstract}




\section{INTRODUCTION}

Much of the recent research in sociolinguistics has aimed to account for new phenomena in a globalised society to better understand processes of power and knowledge production (Coupland 2003; Heller 2011; Blommaert 2010). Issues of translation have remained largely overlooked in 'globalisation-sensitive' sociolinguistics research, despite the fact that decisions on what languages can, cannot or must be used automatically entail consequences for translation (Meylaerts 2011), and ultimately for access to information, opportunities for knowledge production, and equity. This article explores issues of multilingualism, language and translation policy in the field of transnational civil society. I focus on one of the key actors in global governance, namely international non-governmental organisations (INGOs), as these organisations are important global workplaces in the new information- and knowledge-based economy (Castells 2000). INGOs are organised differently than multinational companies and international governmental organisations, and are characterised by a humanist, non-profit ethos (Rubenstein 2015). Many large INGOs have recently undergone huge organizational changes, clustering into federations, associations and international networks, often with tasks from the traditionally Western-based headquarters being decentralised to the East and South (Bond 2015b). Exploring language practices at INGOs is a way to capture some of the new phenomena brought about by globalisation.

By focusing on these issues at the international human rights NGO Amnesty International, this article aims to contribute to debates in a number of disciplines. Firstly, in sociolinguistics and translation studies, the article offers an empirically-grounded account of language and translation policies in a global organisation. It contributes to a growing body of research on language ideologies and multilingualism in NGOs and INGOs in the global political economy (Codó and Garrido 2010; Kahn and Heller 2006; Muehlmann and Duchêne 2007; Pujolar 2007) and on the sociolinguistics of globalisation (Blommaert 2010; Blommaert, 
Collins, and Slembrouck 2005; Coupland 2003; Heller 2011; Maryns 2006). Secondly, in international relations, development studies and political science, the article contributes to ongoing debates on the legitimacy of INGOs, the paradox between INGOs' ethos and their often corporate management style, and INGOs' efforts to bridge the divide between the global North and South (Demars and Dijkzeul 2015; Lang 2014; Rubenstein 2015; Yanacopulos 2015). Overall, I use the case of translation policies at Amnesty International to argue for the need to include aspects of translation in future sociolinguistic research, and for a general move towards more interdisciplinary research to help us understand new phenomena in the context of the rise of language work in the global new economy (cf. Heller 2010), and of INGOs as actors in global governance.

\section{TRANSLATION AS A SOCIAL ACTIVITY AND TRANSLATION POLICY}

In line with sociologically-oriented research in translation studies, I consider translation as a sociological act that is inherently linked to the agents that carry out translation work and who are influenced by the institutions in which translation takes place (Angelelli 2012; Wolf 2007). Translation here is seen as a site of struggle, over who decides what is translated, in what way, in what languages, and who decides what counts as knowledge, legitimate language, or good practice (Heller 2008: 109). My work has been influenced by ethnographic research on translation in institutional settings (Abdallah 2012; Buzelin 2007; Davier 2014; Van Hout and Macgilchrist, 2010), particularly Koskinen's ethnographic study of translation at the EU (2008), and by linguistic ethnography more generally. Even though little of the ethnographic research in translation studies identifies itself as linguistic ethnographic, the two central assumptions that Rampton, Maybin, and Roberts (2015: 18) describe as likely to be shared by linguistic ethnographic researchers are present in much of this work: (1) language and social life are mutually shaping and the social context in which communication (or translation) takes place should be investigated rather than assumed; and (2) the internal organisation of semiotic 
data is essential to understanding its significance and position in the world. I agree with Flynn (2006) that a linguistic ethnography of translation would be 'a logical follow-through of linguistic approaches to translation that have increasingly taken the context of translation into account over the last fifty years' (2006: 45). For translation studies with a sociological grounding, linguistic ethnography, and related approaches such as linguistic anthropology and critical ethnographic sociolinguistics, are appealing because of their (socio)linguistic ethnographic commitment to examining empirical processes in light of the material, real-world changes associated with globalisation, and their ability to challenge established categories (Duranti 1997; Heller 2011; Rampton et al 2015). Linguistic ethnography specifically positions itself as an interdisciplinary region, and researchers from a variety of disciplines have identified their work as linguistic ethnography (Snell, Shaw, and Copland 2015; Tusting and Maybin 2007). In this article, I add a translation studies perspective to this growing interdisciplinary body of research, by combining a linguistic ethnographic framework with concepts of language and translation policy to foster links between micro-data and broader levels of the organisation and extra-institutional context.

Drawing on Interactional Sociolinguistics, Rampton (2007) describes that investigating specific situated communication processes can be wide-ranging and that analysis often involves a variety of foci, such as (1) persons; (2) situated encounters; and (3) institutions, networks and communities of practice. ${ }^{2}$ In line with Hymes' ethnography of communication, meaningmaking is seen as arising in a specific context, as culturally framed and interactively constituted, rather than as a direct reflection of norms, beliefs and values of communities seen as a homogenous, structured whole (Gumperz and Hymes1986). Although these reflections are helpful, they do not take into account translation, neither as a process nor as a product. I argue that translation, just as 'speaking', 'is not just a matter of individuals' encoding and decoding of messages', but that translating, like 'interacting', is 'to engage in an ongoing process of 
negotiation, both to infer what others intend to convey and to monitor how one's own contributions are received' (Gumperz 1999: 454). Translation is a specific form of situated encounter, i.e. a place where the translator and the institution come together. The translator takes particular decisions based on values and beliefs that are contingent on the institutional setting in which s/he works and interacts. These lead to a specific outcome, visible in the translation product. In order to distinguish translations from situated encounters as speech exchanges between individuals, I propose to consider translations here as situated discourse. This enables us to add a focus point specifically related to interlingual transfer, whether written or spoken. Speaking of situated discourse emphasises the fact that the translations are shaped by and participate in shaping the context in which they are produced.

The three focus points (institutional framework, situated encounters and persons) provide a link to the field of language policy. Based on definitions of language policy (Spolsky 2004), translation policy can be defined as encompassing three components: (1) translation practices; (2) translation beliefs; and (3) translation management (González Núñez 2016). This definition not only captures formal elements of policy, but also informal aspects such as personal beliefs. Spolsky (2004) emphasises that the same processes for decision-making which operate at the macro level also operate at the micro level: policies at the national level interact with less obvious policies at levels below and above the nation state, including those of families, schools, religious organisations, the workplace, local government, and supranational organisations (2004: 39,55$)$. In line with this understanding, translation policy is considered as a complex social system, which we explore here in one particular institutional context. Defining translation policy in accordance with Spolsky's definition of language policy recognises the strong connection between the two concepts, i.e. decisions on language policy inevitably include decisions on translation policy (González Núñez 2016; Meylaerts 2011). 
The three focus points for analysis described in Rampton (2007) and Gumperz (1999) could be conceptualised as the three facets of translation policy, i.e. translation beliefs, translation practices, and translation management. Translation products, then, can be considered as the culmination of translation policy's three elements. The integration of the concept of translation policy in a linguistic ethnographic framework can be visualised in a nexus research model (cf. Koskinen 2008), as illustrated in Figure 1, where the object of study is put at the centre and the researcher uses all kinds of data 'to grasp all the relevant connecting lines that form the net around it' (Koskinen 2008: 2). The nexus model helps in conceptualising translation as the product of a complex process involving (a) translators and other agents with their beliefs relating to translation, (b) the institution with its own discourse, ideologies and representations, and (c) situated encounters, or translation practices, as what happens on the work floor (cf. Koskinen 2008).

\section{<Figure 1 here>}

The nexus model allows us to link approaches to multilingualism and translation to its wider socio-political context. Translation policy and translation products ultimately have an impact on the representation of an organisation's message and voice around the world. In particular for Amnesty, the way in which its message and voice is translated will have an impact on whether or not the organisation succeeds in reaching out to citizens, in gaining media attention, in successfully lobbying governments, and eventually, whether or not human rights violations are publicly denounced.

\section{AMNESTY INTERNATIONAL AND TRANSNATIONAL CIVIL SOCIETY}

The international human rights organisation Amnesty International has more than 7 million members worldwide and has offices in about 80 countries. The organisation's roots go back to 
the 'Appeal for Amnesty' campaign that was launched by the British lawyer Peter Benenson in 1961. The campaign was quickly transformed into a permanent international organisation, with Amnesty's first meeting held in the same year and attended by participants from several European countries and the US. London functioned as the organisation's pivot point from early on, when Benenson opened an office and library there, later to become Amnesty's International Secretariat (IS). The organisation's geographical reach and scope of work have grown immensely over the years. Its original focus on Prisoners of Conscience gradually expanded, with a significant change in the early 2000s when Amnesty also started working on social, economic and cultural rights, including work on poverty as a violation of human rights.

The evolution of Amnesty is paradigmatic for the aid sector as a whole. Carbonnier (2016: 60) points out that even in episodes of economic crisis, the humanitarian labour market has continued to grow rapidly. INGOs today span almost every possible sector of human activity, many of them offering their services or working as advocacy organisations in the field of development, humanitarian intervention, or protecting the environment (Davies 2014: 3). Yet INGOs have also been confronted with many challenges as part of globalisation, such as climate change, urbanisation, and demographic and geopolitical shifts (Bond 2015a). With a stronger civil society being formed in the East and South, the legitimacy of Western INGOs has been increasingly criticised, with questions related to on whose behalf they are speaking and advocating becoming more mainstream (Anderson et al. 2012; Bond 2015b; Crack 2013; Lang 2014). INGOs have aimed to address these issues in several ways, for example by increasingly working in partnership with local organisations, and by decentralising the powerful role of traditional headquarters based in the West. This has been achieved through establishing global alliances, federations, confederations, and international networks (e.g. World Vision International, CARE International, Family for Every Child), and for several large UK-based INGOs, by moving their headquarters out of the UK and to the global South (e.g. 
ActionAid moved its headquarters to Johannesburg in 2004). These changes suggest that INGOs as transnational players need to confront the changing power axis in today's globalised world linguistically as well.

Within Amnesty, discussions on how to become more global have been ongoing at least since the 1980s (Hopgood 2006). Most recently, Amnesty has sought to address its claim to legitimacy as a Western INGO through its 'Moving Closer to the Ground' initiative, as part of which it has opened regional hub offices in 'key capitals' (Shetty 2016), including Hong, Kong, Bangkok, Nairobi, Johannesburg, Mexico City, Lima, and Beirut. These hubs assume many of the tasks of the UK-based International Secretariat, and allow Amnesty 'to act with greater legitimacy, speed, capacity and relevance as we stand alongside those whose rights are violated' (Shetty 2016).

These organisational changes of Amnesty as a political force and a global workplace entail the need for a different approach to translation and multilingualism. Amnesty, as many Western-based INGOs, has traditionally worked from English into other languages. Translation into Arabic, French and Spanish, languages that were identified as Amnesty's 'official' and later on as its 'core' and 'strategic' languages, have dominated the translation budget for many years. French and Spanish translation units were set up as part of the IS in the mid-1970s, and were decentralised as dedicated translation units in the mid-1980s, with an office in Paris and in Madrid respectively. Around the same time, Arabic was added to Amnesty's 'official' languages, with a small translation team based at the IS in London. For translation into other languages, local offices were largely dependent on their own resources, and took their own translation decisions. Amnesty's language and translation policy was reviewed many times over the years, most recently in the 2000s as part of Amnesty's efforts to move closer to the ground and to truly become 'One Global Amnesty', the phrase used in internal communication to refer to the restructuration plans. The opening of hub offices implied new translation needs, 
into, and especially from other languages. To cater for these needs, Amnesty set up a Language Resource Centre (LRC) in 2010, a virtual network that brings together the translation staff based in Madrid, Paris and London with other staff dealing with language and translation work in offices around the world. The LRC aims to organise language services more centrally, so that fragmentation can be avoided and funds can be implemented more efficiently. The decentralisation of decision-making and agenda-setting power away from the UK thus led to the need for a more centralised languages and translation service.

Having federated and decentralised at various points in time over the last two decades, other UK-based INGOs are equally dealing with these challenges and new needs. Oxfam launched its internal translation service in 2011; Save the Children has employed a translations manager since 2006; and Tearfund appointed its first translations editor in 2008 after decentralisation. Apart from the apparent rise in language work (cf. Heller 2010) and the need for translation from and into new languages, these organisational changes also challenge the traditional role of English as the lingua franca in development, advocacy and humanitarian work. These issues will be explored in more depth for the case of Amnesty in the analysis below.

\section{DATA AND FINDINGS}

The data drawn on in this article are from my doctoral research on translation policies at Amnesty International (Tesseur 2014), and were collected during the starting period of Amnesty's reorganisation of translation services. The analysis presents a screenshot of how translation was dealt with at Amnesty during the time of fieldwork at Amnesty International Vlaanderen in Antwerp (hereafter Amnesty Flanders, 2 months, in 2012), and at Amnesty International Language Resource Centre Paris Office (hereafter LRC Paris, 1 month, in 2013). Additional interviews with staff at Amnesty's International Secretariat (IS) in London and at LRC in Madrid are used to gain insight into the overall structure of the organisation and the 
ongoing changes. Time at the offices was shared between carrying out tasks for Amnesty, training in complementary skills and collecting research data. I introduced myself overtly as a researcher, and staff were informed of the purposes of my research.

The collected data can be broadly divided into two sets: (1) data concerning the institutional context in which translation takes place, such as policy documents, fieldnotes on meetings and discussions with staff, semi-structured interviews with translators, press officers, etc.; and (2) a comparative corpus of translations, including source and target texts. Interviews were carried out in Dutch at Amnesty Flanders, and in English at the other offices. Translations of the interview data were checked with interviewees.

The text corpus drawn on in this article consists of press releases in three languages: the English source texts produced by the IS, and the French and Dutch translations by LRC Paris and Amnesty Flanders respectively. The corpus contained 403 texts, which were used to explore general features of the texts on the macro-level. Ten source texts with their Dutch and French target texts were selected at random for in-depth analysis. The findings of this detailed analysis were checked against the larger corpus, to ensure representativeness.

For the purposes of this article, I focus on some of the tensions that were laid bare through the interview data and the corpus analysis on issues of controlling Amnesty's voice in different languages and differences in translation policies. The analysis of translation practices, management and beliefs is used to illustrate wider tensions within Amnesty on de/centralisation and the position of English.

\section{Local translation policy at LRC Paris and Amnesty Flanders}

LRC Paris is a small and dedicated translation office, employing about ten staff of which six are internal translators/revisers. Most of the translation work is done by a pool of twenty freelancers, who have worked for LRC Paris for many years. LRC Paris in essence works like a translation company: translations are commissioned by the IS and French-speaking Amnesty 
offices. However, it is often the LRC Paris director who takes the final decision on which documents are translated, depending on the number of offices who requested a translation, the topic and length of the document, the cost involved, etc.

Amnesty Flanders is a local campaigning office, with about twenty paid staff and twenty volunteers and interns who come into the office on a regular basis. Translation is dealt with on an ad-hoc basis, and the office does not employ internal translators. However, most staff translate texts as part of their job role, especially the press and web team. The office is occasionally also able to use translations produced by Amnesty the Netherlands, a much larger office with more resources. Most translation at Amnesty Flanders is from English into Dutch, but there is also some between French and Dutch, for collaborations with the Belgian Frenchspeaking Amnesty office. The different set-up of these offices and the fact that LRC Paris employs professional translators, whereas Amnesty Flanders does not, gave rise to considerable contradictions in the way that translation was understood. The professional translators at LRC Paris had a high regard for translation, and specifically for translating for Amnesty:

\section{Extract 1}

It's not style, it's not that it has to be written in a specific style, it's just that Amnesty texts are very special (...) you have to be very conscious, very careful, the style has to be very precise, a special tone, you don't have to add like 'horrific', or 'atrocities', you have to keep a very sober, and factual tone, that's more efficient (...) sometimes I worked with a journalist, like we say he had a, 'une bonne plume', he wrote a journalistic style, that didn't work for us, because you, you don't have to add anything, it's boring, it's really boring, but the way it has to be for -, because it's too important, even an Urgent Action, if you say more than what's in the text then you change the purpose, and you change the message. (Interview \#6) 
According to this translator, Amnesty maintains a specific writing style, which needs to be mastered to be able to deliver high-quality translations. S/he continues by explaining that not all texts require the same sober style, but that translating facts correctly is essential for every type of document:

\section{Extract 2}

Public statements for example, they are used by groups that work on a special country, like in France there are 280 groups, they -, sometimes, public statement might be the only document they have on a situation in Myanmar, for example, or in uh -, and so they will work on the information they have there, and write to the authorities or something, so they have to be, to trust exactly what is, uh, and if you say 'arrested' instead of something else, then you, you -, every word is important, every -, you cannot, cannot play with that. (Interview \#6)

This emphasis on accuracy up to the level of the word is an important characteristic in translating for Amnesty in the view of all the translators working at LRC Paris. Translation is considered as a professional activity that requires a lot of specific knowledge. Training, revision, and the use of translation software were considered essential, and were all in place at this office.

Conversely, at Amnesty Flanders, translation was carried out by volunteers and staff who were not trained in translation and whose main duty was not translation work. For example, one of the most pressing translation needs at Amnesty Flanders is that of Urgent Actions. These are 1-2 page documents that urge Amnesty activists to take action (to write, email, text, etc. to governments and other political actors involved) on emergency cases of human rights abuses. At Amnesty Flanders, these texts are translated by volunteers who work from home, and the translations are seldom revised. The pool of volunteers consists of approximately eighty people, ranging from professional translators to language students and retirees without translation training. New translators were asked to pass a translation test, which 
was more an administrative formality: no one had ever failed the test. Guidelines for the translation of Urgent Actions were limited to a two-page document focused on lay-out rather than translation. This suggested a view of translation as a simple activity, that could easily be performed by volunteers without providing any training. Press releases were translated by a local press officer who kept a close watch on legal terminology, the only aspect of translating for Amnesty that was considered complex. Yet even in this case, available tools were limited to a list in (Flemish) Dutch and English with acts and laws that were commonly referred to in Amnesty texts. When asked about the difficulty of translating press releases, an Amnesty Flanders press officer related:

\section{Extract 3}

dat is altijd wat schipperen tussen mensen die jurist zijn, en die dat, als ik dat hier, intern, bij sommige collega's laat lezen: 'ja maar ja dat is toch niet helemaal juist', maar als je het helder gecommuniceerd wilt krijgen, en ook, als het aantrekkelijk moet zijn voor journalisten, als ze het moeten oppikken, ja dan, dan moet je zo toch wel ergens een middenweg vinden hè.

[it's always about finding a compromise between people who are trained lawyers, and who, when I, here, internally, let some of the colleagues read it, 'yes okay but this is not quite right', but if you want things clearly communicated, and also, if it needs to be appealing to journalists, if they have to pick it up, well then, then you do need to find a middle ground somehow.] (Interview \#4)

This view of finding a middle ground between correct language use and idiomaticity is very different from that expressed by translators at LRC Paris. These contradictory views of translation as a professional skill versus as a simple activity recall the views of NGO workers in Kahn and Heller's study (2006) regarding language knowledge: either language knowledge was constructed as a professional and technical skill, or as an authentic and personal talent, which in that case was left unremunerated (see also Boutet (2001)). The beliefs relating to translation as a professional skill or a simplistic activity at Amnesty are closely linked to local 
translation practice: the lack of training, revision mechanisms, and absence of translation software at Amnesty Flanders were very different from LRC Paris’ practices.

\section{Textual analysis}

For the purposes of this article, I focus on the translations of quotations in press releases. I pursue the question whether any differences can be found in the translations by Amnesty Flanders and by LRC Paris, and if the different institutional arrangements were reflected in the translations.

Whereas the translations of quotations by LRC Paris rarely included any changes, Amnesty Flanders's translations contained shifts on a regular basis. One particular feature was that quotations were often attributed to different speakers. For example, a quote by a staff member working at Amnesty's IS in the source text would in the target text be translated and attributed to a local staff member of Amnesty Flanders, often the director of the local office, as illustrated in the extract below.

\section{Extract 4}

\section{AI IS}

'The stalemate that is keeping more than half a million people from their homes cannot be allowed to continue,'said Gaëtan Mootoo, Amnesty International's West Africa researcher.

'The authorities must act to establish a clear chain of command and disband militia groups who, despite the end of the conflict, continue to spread fear among the population.'

\section{Amnesty Flanders}

'Deze wurggreep die meer dan een half miljoen mensen weg houdt van hun huizen kan echt niet blijven duren,' zegt Karen Moeskops, directeur van Amnesty International. 'De autoriteiten moeten hun troepen weer onder controle krijgen en de milities ontbinden die, ondanks het einde van het conflict, angst en terreur blijven zaaien onder de bevolking.'

['This stranglehold which is keeping more than half a million people away from their homes can really not continue', says Karen Moeskops, director of Amnesty International. 
'The authorities need to regain control of their troops and disband the militia who, despite the end of the conflict, continue to spread fear and terror among the population.']

These shifts in attribution show how Amnesty's voice can change in translation. The quotations were sometimes also adapted to the local context, replaced by new quotations from a local spokesperson, or simply omitted:

\title{
Extract 5
}

\author{
AI IS \\ 'Kosovo has so far shown absolutely no willingness to make sure that members of minority \\ communities who are forcibly returned, are properly reintegrated in the community,' said Sian Jones, \\ Amnesty International's Balkan researcher. \\ 'Without proper measures to address the severe discrimination faced by Roma in Kosovo, their \\ removal there may lead to them facing persecution. The Belgian, Dutch and Luxembourg authorities \\ must immediately halt these repatriations.'
}

\begin{abstract}
Amnesty Flanders
'Ondanks de aanname van wetgeving en een actieplan bijna aan jaar geleden, beschikken de autoriteiten nog steeds niet over de nodige fondsen, middelen of politieke wil om te voorzien in een duurzame terugkeer', aldus Carmen Dupont, beleidsverantwoordelijke bij Amnesty International Vlaanderen.

['Despite the adoption of legislation and an action plan almost a year ago, the authorities still do not possess the necessary funds, resources or political will to provide for a sustainable return', said Carmen Dupont, policy officer at Amnesty International Flanders.]
\end{abstract}

Parts of the first quotation are adapted and attributed to a local spokesperson. The second quotation, calling on the Belgian authorities to take action, is omitted. Elsewhere in the translated press release, there is an addition stating that 'by signing the removal agreement the 
Benelux countries close their eyes to the risk of persecution of minorities'. Thus, the Flemish press release still criticises the Belgian authorities, yet it does not call it to action as explicitly as the English original text does.

\section{Linking local practice and beliefs to global issues: becoming One Amnesty}

Combining the data on local translation policy, the textual analysis of press releases, and the wider socio-political context in which Amnesty operates allows insight into the underlying reasons for some of the changes in the translations, in particular the reattribution of staff members' quotations. In itself, the reason why Amnesty Flanders's press office was reattributing quotations was quite straightforward: choosing a local representative of the organisation increases the chance of local media contacting Amnesty Flanders and picking up the press release, especially for radio and television news (Tesseur 2013: 12). Jacobs (1999) has argued that because the main function of press releases is to be retold, they are often 'preformulated', containing a number of features that make it easier for the journalist to copypaste the ready-made text: press releases tend to be written in the third person, are neutral in time and place, and have a newspaper-like heading and lead paragraph. Research has also shown that quotations in press releases are often pseudo-quotations, i.e. they were never verbalized by the named source, but created by press officers (Bell 1991; Sleurs et al. 2003). The practices at Amnesty Flanders of reattributing quotations seem a logical follow-through of the use of pseudo-quotations: replacing the name of someone who did not verbalize the words between quotations marks in the first place. Moreover, because both spokespersons in the source and target text are speaking as representatives of Amnesty, the institutional voice is maintained (Jacobs 1999).

Despite the logic behind the practice, staff members at LRC Paris and at the International Secretariat were not only ignorant of the fact that some Amnesty offices 
reattribute quotations, but were also surprised and in some cases outraged when hearing about this practice (Tesseur 2013). A press officer at Amnesty Flanders related:

\section{Extract 6}

er zijn helemaal geen richtlijnen om voor de vertaling. Het Internationaal Secretariaat gaat er wel van uit dat alles, zeker de quotes, letterlijk wordt overgenomen. Ik heb, toen ik op bezoek was op het Internationaal Secretariaat, mensen van hun stoel zien vallen toen ik zei dat ik de quotes aan andere mensen toekende. De reacties waren eerst vol verbazing, en gechoqueerd. Maar als je het dan uitlegt, begrijpen ze het wel, en na een paar minuten knikte iedereen instemmend en begrijpend. Het belangrijkste is uiteindelijk dat het Amnesty standpunt hetzelfde blijft. Moest dat veranderd worden, dat zou rampzalig zijn.

[there are no guidelines at all for the translation. The International Secretariat does assume that everything, especially the quotations, are taken over literally. When I visited the International Secretariat, I saw people nearly falling off their chairs when I said I attributed quotations to different speakers. The reactions were first full of astonishment, and shock. But if you then explain, they do understand, and after a few minutes everyone was nodding in agreement and understanding. The most important part is in the end that Amnesty's point of view remains the same. If that were changed, that would be disastrous.] (Interview \#14)

The interviewee continued to relate that during this visit, some press officers from other Amnesty offices reported implementing the reattribution practice as well, while others said they would never reattribute quotations and found the practice strange. The London press officers, the interviewee reported, 'clearly had never thought about this, that quotations may be adapted on a local level' ('die hadden daar duidelijk nog nooit over nagedacht, dat dat op lokaal niveau wel eens zou kunnen aangepast worden', interview \#14).

These different practices, and the mistaken assumptions about what is and what should be common practice, show that within Amnesty as an organisation, there are fundamentally different understandings of translation as a process and product. Whereas at LRC Paris, 
translation was seen as mere transposition, with no changes to be made to the source text, Amnesty Flanders adapted press releases to the local media's interests, and translation was seen as a means to an end.

The different understandings of translation of Amnesty Flanders and LRC Paris, and by extension staff at its IS, as mentioned by Amnesty Flanders' press officer, can be linked to wider tensions in the organisation about the level of control exercised over Amnesty's message and voice. These discussions already appeared during the 1970s, a time of huge expansion for Amnesty. In his study of the history and development of Amnesty's International Secretariat, Hopgood (2006) relates that Amnesty decentralised part of its research to an outpost in Paris in the 1970s, and that national offices were given enhanced capacity to allow them to serve their own member groups. The potential dangers of this were underlined in Amnesty documents from 1977, stating that 'Decentralization will necessitate a strict observance of AI principles and procedures in order to ensure that a single AI identity is preserved and that AI speaks with one voice on all levels of the organization in all parts of the world, instead of with as many different voices as there are national sections' (as quoted in Hopgood 2006: 84). By 1984, Amnesty had implemented a strict approval system to assure quality control of its research and other publications, including press releases, newsletters, Urgent Actions, its research reports and Annual Report, etc. To get a document approved, several people would have to give the go-ahead, with the final text to be approved by the Secretary General. Although Amnesty's previous slogan of 'one movement, one voice' was replaced in 1987 by 'one movement, one message, many voices', in an effort to recognise the need for openness, change, flexibility, diversity and innovation, Amnesty as an organisation has kept on struggling with finding a balance between maintaining control of its message and letting go. Around 20112013, when the data used in this article were collected, the tightly controlled, bottleneck approval structure still seemed to be in place for much of the material. This was a huge problem 
for the new decentralised structure, particularly because the bottleneck structure that documents had to pass through was organised in English. One interviewee explained:

\section{Extract 7}

At the moment, everything is approved in English, so everything that is not done in English needs to be translated into English, needs to be approved in English, and then it needs to be back-translated into that language (...) This is the line of work. But one of the things that we are trying to implement is that let's not approve everything in English. I mean, if something is generated in French or in Spanish, there should be someone able to say: okay, this content is correct, and I'm approving it in French, in Spanish, or Chinese (...) At the moment that is causing a lot of, of uh, turmoil in London, because obviously, that will (...) some of them will lose their authority, or their power to say: this has the green light and this doesn't for example. But obviously this is coming, this is the reality. This was decided by Amnesty a couple of years ago, so it's not something a manager has decided, and Amnesty has decided to go this way, and the LRC needs to be ready to support this kind of, uh, of means. (interview \#02)

To some extent, this procedure contradicts the way that Amnesty has positioned itself over the last few years: as a global organisation that is present on the grassroots level, presenting a variety of voices. It reveals the internal tensions that Amnesty is experiencing. Decisionmaking power on research and publications has traditionally been with the IS. Having originated as translation services within the IS during the 1970s, the LRC Madrid and Paris offices have historically taken the same meticulous care to get Amnesty's message right before it goes out to governments, newspapers, academics, etc. For the staff working at these translation offices, the organisational changes that the translation services were going through at the time of fieldwork brought with them many insecurities and questions on how work would be organised, what money would go to which languages, and how Amnesty would maintain its message and voice through translation, especially in the light of the One Amnesty ideal. These 
insecurities and fears are apparent in Extract 8 below from an interview with a Paris translator, where 'I' stands for interviewer and ' $\mathrm{R}$ ' for respondent.

\section{Extract 8}

I: What about Amnesty's message? If it's going global and it wants to translate into more languages at the same time, it's creating hubs, what's going to happen to that message? -

R: (overlapping) I asked, I asked that question already in a meeting, with top people, and, I didn't get any clear answer

I: no

R: $\quad$ uh, I do believe that they told me it was a problem (laughs) -

I: $\quad$ okay (laughs)

R: $\quad$ but of course the solutions were going to be found (laughs) (Interview \#8)

The respondent explained that the practical implementation of One Amnesty involved controlling all the hubs centrally. The hubs should work according to the principle of One Amnesty, in which everyone conveys the same message. Yet how control on this level would be achieved remained unclear. S/he continued:

\section{Extract 9}

I think it is going to be very difficult to ensure that everybody does carry the same message. I was thinking that we're going to need an Amnesty police! (laughs) No, that is going too far, but you see what I mean. (Interview \#8)

Although the respondent takes back the idea of an 'Amnesty police' immediately, and s/he expressed the idea with a laugh, it indicates his/her fears relating to what will happen to the organisation and its message. In general, the fears that translators harbour concerning the accurate transmission of Amnesty's message and voice is closely related to an overall concern about Amnesty's growth plans, and more particularly about the risk of Amnesty losing its credibility by expanding too much. 
Yet these fears and beliefs relating to accuracy and Amnesty's reputation are not shared throughout the organisation, as illustrated in Extract 10 from an Amnesty Flanders press officer.

\section{Extract 10}

'Communicatie hangt heel erg af van het lokale medialandschap. Het zou ook niet goed zijn als het van bovenaf was opgelegd. Want elke lokale context is anders. Sommige landen kunnen ook geen Engels, dus daar kan je niet, zoals ik wel vaak doe, persberichten in het Engels uitsturen. Daar is bijvoorbeeld ook vaak een grotere geografische afstand met Londen, en het is vaak belangrijk, bijvoorbeeld voor een sectie die pas is opgericht, dat er net veel lokale communicatie is, om de groei van de sectie te bevorderen.'

['Communication is very much dependent on the local media landscape. It wouldn't be a healthy situation either if everything was imposed from above. Because every local context is different. Some countries don't speak English, so you can't, like I do quite often, send out press releases in English. There is also quite often a large geographical distance to London, for example, and it is often important, for example, for a section that has only just been set up, that there is a lot of local communication, to stimulate the growth of the section.' Interview \#14]

The press officer's interpretation of how Amnesty should be governed is one where the grassroots level defines Amnesty and speaks as Amnesty, rather than a centrally governed voice.

On top of these different visions of Amnesty, the way that information is produced and is spread has changed immensely in light of globalisation, and so have the organisation's needs. When asked about the organisation of translation work, one interviewee commented:

\section{Extract 11}

I think the issue is what is external reality, and how this external reality is changing, because we cannot live in the 1970s you know, because there are things called iPads and Facebook, and Twitter, and all of 
that, and we cannot possibly... we have received a great amount of pressure to do things quicker (Interview \#13)

These citations reveal the difficulty of maintaining 'one voice' and of having one Amnesty identity within an abundance of media channels and types of information that are produced and translated at different levels of the organisation. Furthermore, they also illustrate the contrasting views held by people at different levels and in different functions in the organisation the need to control Amnesty's message, whether in English or in translation.

The analysis highlights the working realities and paradoxical tensions that INGOs are confronted with in their position as actors of global governance, aiming to fulfil their ethical obligations to represent grassroots voices from the East and South and to challenge the traditional powerful position of English as the main language of communication, and as major actors in the new global economy, with pressure for more and faster information, while they have only limited resources.

\section{CONCLUDING REMARKS}

This article has used the case of Amnesty International to shed light on how INGOs deal with language needs as global workplaces in the new global economy. Considering INGOs as major political actors in global governance, the article highlighted the importance of language and translation policies in light of the current pressures in the aid field, in which INGOs aim to maintain their legitimacy by decentralising their traditionally Western-based headquarters. Using the concept of translation policy, I described Amnesty's efforts to centralise its translation services as a response to its decentralising organisational structure and subsequent increased translation needs. The analysis revealed that during the early period of this centralisation process (2011-2013), translation management, practices and beliefs varied to a great extent depending on the office and the language. There was no shared understanding in 
the organisation of what translation entails, although there was a general assumption that everyone knows what is understood by translation at Amnesty. The analysis of translated press releases showed that differences in translation policy led to differences in the translations.

On an ideological level, the discussion revealed that de/centralising the control over Amnesty's voice, and challenging the use of English as the main internal language, are highly complex in an organisation that has many different levels in distant geographical locations, with different needs. These tensions and complexities are faced by many Western INGOs that have expanded over the last few decades and aim to represent a large variety of people, who speak different languages. Financial constraints make it extremely difficult for INGOs to disestablish the powerful role of English, or of other mainly European languages that many INGOs have adopted as official or core languages, such as French or Spanish. Due to globalisation, the amount of material that large INGOs produce has increased significantly and there is a lot of pressure to produce materials and their translations ever more quickly, burdening INGOs with difficult choices on which materials - and which voices - to translate from and into which languages, and what resources to dedicate to this. Over the last few years, the use of English in the aid sector as a whole has started to be challenged. Yet despite these concerns articulated by the sector itself (Cornwall and Eade 2010; Powell 2006), there is very little discussion of issues of multilingualism, translation and the position of English in development studies or international relations research. This article opens up a space to start discussing these issues in a much more interdisciplinary setting.

Translation as a communicative activity is often taken for granted. In this article, I have aimed to demonstrate that translation is a social activity, a site of struggle occupied by many actors with different power positions bound to different institutional ideologies. The textual analysis of press releases has shown that discourse can change in translation, and the analysis of local translation policy revealed that there are many aspects that can have an influence on 
meaning-making, voice and access in translation. These findings support my argument that greater attention should be paid to translation processes in sociolinguistic research, and indeed, in international relations and development research that focuses on the transnational, and inevitably multilingual, working spaces of INGOs. In order to fully understand the language practices under investigation in a sociolinguistics of globalisation, practices of translation must be foregrounded and conceptualised as integral elements of any study aiming to shed light on the changing role of multilingual repertoires and practices in the globalised economy.

I further would argue that investigating the language and translation policies of INGOs enhances our understanding of how these actors in global governance 'translate' their discourse of being global, multicultural organisations into action, opening up a window for sociolinguistics and translation studies to engage in conversations on the legitimacy of INGOs that are currently taking place in international relations, development studies and the aid field itself. Sociolinguistics and translation studies can contribute by drawing attention to the problematics of the traditionally powerful position of English, by revealing some of the underlying power relationships and mechanisms, and by formulating ideas on how to counteract some of these mechanisms, in order to address inequalities and tensions over whose voice is able to cross language borders and be heard on a global scale. 


\section{NOTE}

1

Paper written with reference to Translation Research Training: An integrated and intersectoral model for Europe (FP7-PEOPLE-2010-ITN-263954). EU Seventh Framework Marie Curie Initial Training Networks (ITN), 20112014. The author would like to the peer-reviewers for their helpful comments on earlier versions of this article. 2

These three focus points can also be recognised in Koskinen's (2008) study of translation at the EU. Emphasising that the work of translators is influenced by several factors, her study is built on three levels of analysis: the study of (1) the institutional framework; (2) the translators working in these institutional settings; and (3) translated documents and their source texts (Koskinen 2008: 6). Koskinen's research is 'a study of both texts and people in their institutional habitat' (2008: 6). 


\section{REFERENCES}

Abdallah, Kristiina. 2012. Translators in Production Networks: Reflections on Agency, Quality and Ethics. Unpublished PhD Thesis. University of Eastern Finland.

Anderson, Mary B, Dayna Brown, and Isabella Jean. 2012. Time to Listen: Hearing People on the Receiving End of International Aid. Cambridge, Massachusetts: CDA Collaborative Learning Projects.

Angelelli, Claudia. 2012. The Sociological Turn in Translation and Interpreting Studies. Translation and Interpreting Studies 7 (2): 125-28.

Bell, Allan. 1991. The Language of News Media. Oxford: Blackwell.

Blommaert, Jan. 2010. The Sociolinguistics of Globalization. Cambridge: Cambridge University press.

Blommaert, Jan, James Collins, and Stef Slembrouck. 2005. Spaces of Multilingualism. Language and Communication 25 (3): 197-216.

Bond. 2015a. Fast Forward: The Changing Role of UK- Based INGOs. https://www.bond.org.uk/resources/fast-forward.

Bond. 2015b. Tomorrow's World: How Might Megatrends in Development Affect the Future Roles of UK-Based INGOs ? London. https://www.bond.org.uk/resources/tomorrowsworld.

Boutet, Josiane. 2001. La Part Langagière Du Travail : Bilan et Évolution. Langage et Société 98: $17-42$.

Buzelin, Hélène. 2007. Translations 'in the Making.' In Constructing a Sociology of Translation, edited by Michaela Wolf and Alexandra Fukari, 135-70. Amsterdam: John Benjamins. 
Carbonnier, Gilles. 2016. Humanitarian Economics: War, Disaster and the Global Aid Market. New York: Oxford University Press, USA.

Castells, Manuel. 2000. The Rise of the Network Society. The Information Age: Economy, Society and Culture, Volume 1. $2^{\text {nd }}$ ed. Malden; Oxford: Blackwell.

Codó, Eva, and Maria Rosa Garrido. 2010. Ideologies and Practices of Multilingualism in Bureaucratic and Legal Advice Encounters. Sociolinguistic Studies 4 (2): 297-332.

Cornwall, Andrea, and Deborah Eade (eds.). 2010. Deconstructing Development Discourse: Buzzwords and Fuzzwords. Rugby: Practical Action Publishing with Oxfam GB.

Coupland, Nikolas. 2003. Introduction: Sociolinguistics and Globalisation. Journal of Sociolinguistics 7 (4): 465-72.

Crack, Angela Maria. 2013. Language, Listening and Learning: Critically Reflective Accountability for INGOs. International Review of Administrative Sciences 79 (4): 80928.

Davier, Lucile. 2014. The Paradoxical Invisibility of Translation in the Highly Multilingual Context of News Agencies. Global Media and Communication 10 (1): 53-72.

Davies, Tom. 2014. NGOs: A New History of Transnational Civil Society. New York: Oxford University Press.

Demars, William E., and Dennis Dijkzeul (eds.). 2015. The NGO Challenge for International Relations Theory. London: Routledge.

Duranti, Alessandro. 1997. Linguistic Anthropology. Cambridge: Cambridge University press. Duranti, Alessandro. 2003. Language as Culture. Current Anthropology 3: 323-47.

Flynn, Peter. 2006. A Linguistic Ethnography of Literary Translation: Irish Poems and DutchSpeaking Translators. Unpublished PhD thesis. Ghent University.

González Núñez, Gabriel. 2016. On Translation Policy. Target 28 (1): 87-109.

Gumperz, John J. 1999. On interactional sociolinguistic method. In Talk, Work and 
Institutional Order, edited by Srikant Sarangi and Celia Roberts, 453-472. Berlin: Mouton de Gruyter.

Gumperz, John J. and Hymes, Dell (eds.). 1986. Directions in Sociolinguistics: the Ethnography of Communication. Oxford : Basil Blackwell.

Heller, Monica. 2008. Language and the Nation-State: Challenges to Sociolinguistic Theory and Practice. Journal of Sociolinguistics 12 (4): 504-24.

Heller, Monica. 2010. The Commodification of Language. Annual Review of Anthropology 39 (2010): 101-14.

Heller, Monica. 2011. Paths to Post-Nationalism: A Critical Ethnography of Language and Identity. New York and Oxford: Oxford University Press.

Hopgood, Stephen. 2006. Keepers of the Flame: Understanding Amnesty International. Ithaca and London: Cornell University Press.

Kahn, Emmanuel, and Monica Heller. 2006. Idéologies et Pratiques Du Multilinguisme Au Québec. Luttes et Mutations Dans Un Site de La Nouvelle Économie. Langage et Société 118 (4): 43-63.

Koskinen, Kaisa. 2008. Translating Institutions: An Ethnographic Study of EU Translation. Manchester: St. Jerome.

Lang, Sabine. 2014. NGOs, Civil Society, and the Public Sphere. Cambridge: Cambridge University Press.

Maryns, Katrijn. 2006. The Asylum Speaker: Language in the Belgian Asylum Procedure. Manchester: St Jerome.

Meylaerts, Reine. 2011. Translation Policy. In Yves Gambier and Luc van Doorslaer (eds.). Handbook of Translation Studies 2. Amsterdam \& Philadelphia: John Benjamins. 163168.

Muehlmann, Shaylih, and Alexandre Duchêne. 2007. Beyond the Nation-State: International 
Agencies as New Sites of Discourses of Bilingualism. In Bilingualism: A Social Approach, edited by Monica Heller, 96-110. London: Palgrave.

Powell, Mike (2006). Which knowledge? Whose reality? An overview of knowledge used in the development sector. Development in Practice 16(6): 518-32.

Pujolar, Joan. 2007. Bilingualism and the Nation-State in the Post-National Era. In Bilingualism: A Social Approach, edited by Monica Heller, 71-95. London and New York: Palgrave Macmillan.

Rampton, Ben. 2007. Linguistic Ethnography, Interactional Sociolinguistics and the Study of Identities. In Working Papers in Urban Language \& Literacies 43. London: King's College London.

http://www.kcl.ac.uk/sspp/departments/education/research/ldc/publications/workingpape rs/43.pdf.

Rampton, Ben, Janet Maybin, and Celia Roberts. 2015. Theory and Method in Linguistic Ethnography. In Linguistic Ethnography: Interdisciplinary Explorations, edited by Julia Snell, Sara Shaw, and Fiona Copland, 14-50. London: Palgrave Macmillan.

Rubenstein, Jennifer. 2015. Between Samaritans and States: The Political Ethics of Humanitarian INGOs. Oxford: Oxford University Press.

Shetty, Salil. 2016. Globalising Amnesty International. Disrupt and Innovate, February 23. https://disrupt-and-innovate.org/globalising-amnesty-international/.

Sleurs, Kim, Geert Jacobs, and Luuk Van Waes. 2003. Constructing Press Releases, Constructing Quotations: A Case Study. Journal of Sociolinguistics 7 (2): 192-212.

Snell, Julia, Sara Shaw, and Fiona Copland (eds.) 2015. Linguistic Ethnography: Interdisciplinary Explorations. Basingstoke: Palgrave Macmillan.

Spolsky, Bernard. 2004. Language Policy. Cambridge: Cambridge University Press. 
Tesseur, Wine. 2013. Amnesty International's language strategy put into practice: A case study of the translation of press releases. In Emerging Research in Translation Studies: Selected Papers of the CETRA Research Summer School 2012. CETRA papers online, edited by Gabriel González Núñez, Yasmine Khaled, and Tanya Voinova. Leuven: KU Leuven. http://www.arts.kuleuven.be/cetra/papers/files/tesseur.

Tesseur, Wine. 2014. Transformation through Translation: Translation Policies at Amnesty International. Unpublished PhD Thesis. Aston University, Birmingham.

Tusting, Karin, and Janet Maybin. 2007. Linguistic Ethnography and Interdisciplinarity: Opening the Discussion. Journal of Sociolinguistics 11 (5): 575-83.

Van Hout, Tom, and Felicitas Macgilchrist. 2010. Framing the News: An Ethnographic View of Business Newswriting. Text \& Talk 30 (2): 169-91.

Wolf, Michaela. 2007. Introduction: The Emergence of a Sociology of Translation. In Constructing a Sociology of Translation, edited by Michaela Wolf and Alexandra Fukari, 1-36. Amsterdam and Philadelphia: John Benjamins.

Yanacopulos, Helen. 2015. International NGO Engagement, Advocacy, Activism: The Faces and Spaces of Change. Basingstoke: Palgrave Macmillan. 
FIGURE 1: NEXUS RESEARCH MODEL

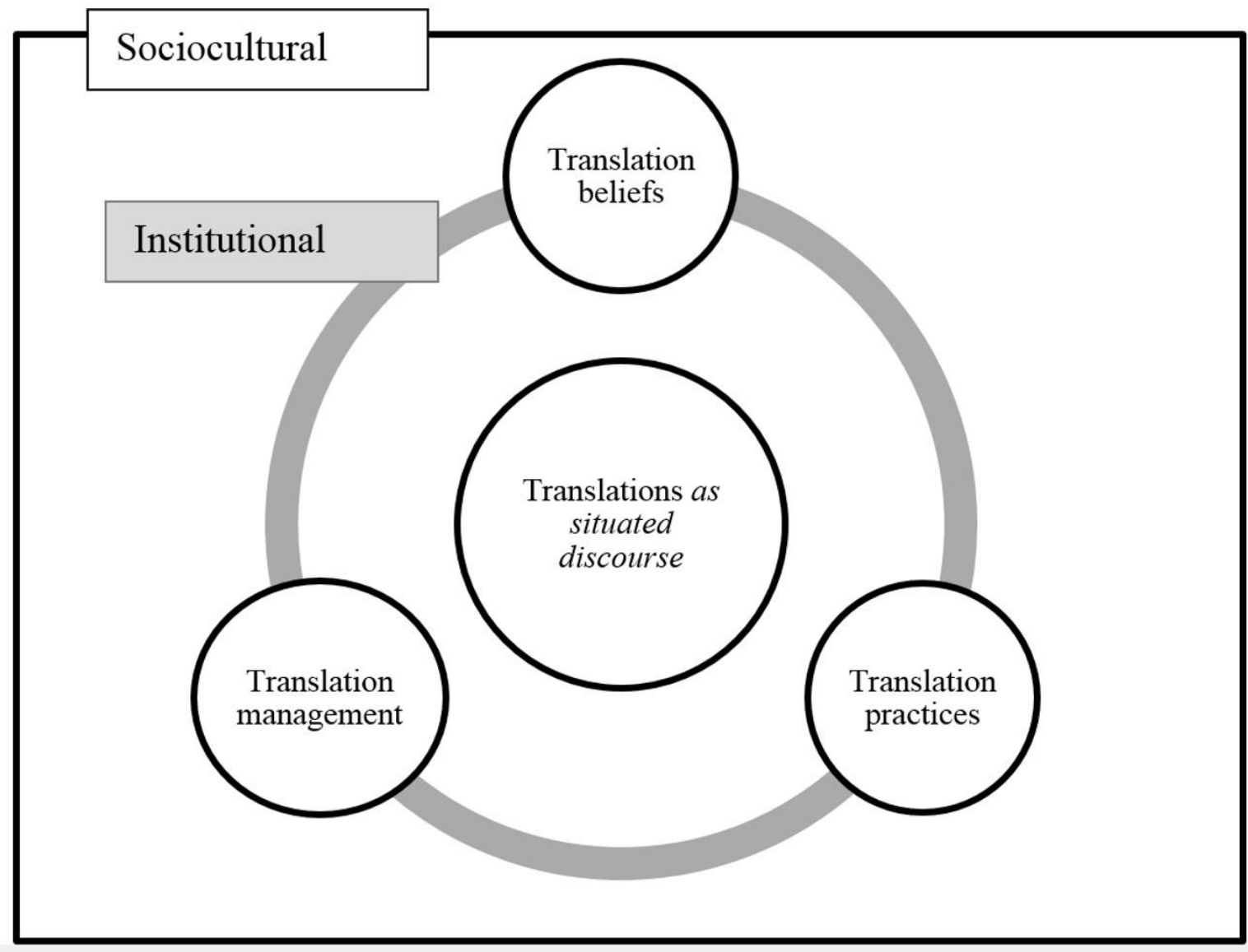

